\title{
Robo-Revolution: A Marxist Approach to Social Uprising in the High-Tech Age
}

\author{
Lika Rodin \\ $\mathrm{PhD}$, Lecturer in Social Psychology, University of Skövde, Sweden \\ Address: Högskolevägen, Box 408, Högskolan i Skövde, Sweden 54128 \\ E-mail: lika.rodin@his.se
}

\begin{abstract}
With the increasing role of technological agents in contemporary society, questions surrounding the future of socio-economic organization are intensely debated. A variety of predictions have been made, ranging from conservative views that emphasize the gradual integration of techno-actors into human social collectives to radical outlooks that assume the inevitability of a dramatic historic break. This study employs the method of simulation, exploring the ongoing path towards automation with the help of classical Marxism. It seeks to understand whether robots and artificial intelligence (AI) might become new value producers and a revolutionary social class. As demonstrated, the continuity of capitalist relationships may facilitate the formation of new social groups and recast class-based political agendas.
\end{abstract}

Keywords: humanoid robots, artificial intelligence (AI), technological singularity, trans-humanism, alienation, The Law of the Tendency of the Rate to Profit to Fall

\section{Introduction}

Robotization is a feature of contemporary times in both advanced and developing countries (Sirkin, Zinser, Rose, 2015). The discussion on the possible effects of robotization on human civilization has recently entered a new phase in which enthusiastic rhetoric coexists with increasing concerns. While the image of autonomous artificial agents has been present in public discourse and popular culture since the early days of the industrial era, the specific term "robot" first appeared in 1920 in Karel Capek's theatrical play R.U.R. It initially referred to a docile population of manufactured beings, whose aim was to carry out industrial and other types of work which served human needs (Ichbiah, 2005; Higbie, 2013; Rubin, 2011). Written in a period of the increasing mechanization of production and revolutionary movements in Eastern Europe, the play opened up not only a public but also an academic discussion on the future of (1) the working class and (2) humanmachine relationships (Higbie, 2013).

The first of these interrelated themes is currently represented by writings on the role of automata in labor market transformations. Scholars reflect upon the prospective degradation of working conditions and the destabilization of traditional earning opportunities resulting from the forthcoming incorporation of robots into production processes (Blit, Amand, Wajda, 2018; Brynjolfsson, McAfee, 2014; Cameron, 2017; Chace, 2015,

(C) Rodin L., 2019

(C) Centre for Fundamental Sociology, 2019

DOI: $10.17323 / 1728-192 \mathrm{X}-2019-3-224-244$ 
2016; Dunlop, 2016; Fleming, 2019; Frey, Osborne, 2017; Ford, 2015; Kaplan, 2015; Sharp, 2018; Spencer, 2018; Tegmark, 2017). Robo-politics, moreover, explores new technologies as means employed by powerful institutions and corporate capitalism to maintain control over the population (Kiggins, 2018; Wilsh, Sculos, 2018). The second theme is dominated by the concern over power relationships, including robo-ethics, which assumes the primacy of human will behind the development and operation of smart machines (Keiper, Schulman, 2011; Rubin, 2011) and what can loosely be defined as "technological singularity" research, an evolutionist and determinist vision of technological agency as an unquestionable successor of humans (Bostrom, 2014; Eden et al., 2013a; Potapov, 2018; Tegmark, 2017; Goertzel, Goertzel, 2015a).

The discussion on the potentials and effects of nonhuman agency frequently evokes an image of transformative militancy. In 2018, American science fiction writer and NASA consultant David Brin, in an interview with the media source Afisha Daily, identified prospective techno-social unrest in terms of proletarian revolution (Vladimirskiy, 2018), a class-based uprising aimed to overthrow the market-driven socio-political system. Apart from Capek's initial play, this scenario has remained underexplored, both in popular culture and in academic work; however, it calls for special attention in the current context of sharpening class division in high-tech societies (Fleming, 2019). The idea of a proletarian revolution and the analysis of mechanisms underlying its potential outbreak were developed by classical Marxism, which seems to be a relevant starting point for my discussion on the perspective of nonhuman, anti-capitalist mobilization. In this paper, I explore the ongoing path towards automation, and Marx's observations regarding the first industrial revolution become particularly useful.

This study positions itself within the field of the sociology of the future, which attends to the social aspects of forthcoming technological innovations (Wendell, 1996). The aim is "to invent, evaluate, and propose possible and probable futures, helping people to explore their alternatives, to decide what future they want, and to design effective action to achieve it" (Ibid.: 45). I employ the method of simulation, which has already gained recognition in the fields of computer science and environmental and population research (e.g. Law, Kelton, 1991; Meadow et al., 1972). In computer sciences, simulation is defined as the imitation of actual processes (Law, Kelton, 1991: 1). Simulation research begins with the idea of a system and related explanatory presuppositions assembled by a network of interrelations in the simulation model. The ambition is to describe and explain the system's operation using this model. The simulation of complex systems may not always be content with straightforward mathematical calculations and requires a certain degree of approximation. For example, the task of assessing the profitability of a plant's future enlargement may involve simulation. In this context, "a careful simulation study could shed some light on the question by simulating the operation of the plant as it currently exists and as it would be if the plant were expanded" (Ibid.: 2; original emphasis). I assume Marx's analytical description of capitalist development to be a simulation model that is applicable to the analysis of the foreseen transformation of production. The Marxist approach is increasingly employed in the analysis of technologically advancing societ- 
ies, providing evidence of its relevance to contemporary, post-industrial conditions (see Fisher, Fuchs, 2015; Fuchs, 2014, 2016a, 2016b; Fuchs, Mosco, 2016; Walsh, Sculos, 2018). Previous research, media and cultural texts constitute working materials for my "mental experiment."

The paper consists of three parts. First, I will outline Marx's model of capitalism, including his views on the ontology and role of machines in capitalist society. My intention is to describe the model to be subsequently employed in the simulation process, rather than to problematize it. A short overview of contemporary advances in robotics will follow to provide groundwork for the final discussion on the prospects of robots and artificial intelligence (AI) becoming a new revolutionary class, as well as the related social, economic and political effects.

\section{Marx's Model of Capitalism}

In a very schematic manner, Marx's arguments can be summarized as follows. Capitalist society gradually emerged from previous social forms: (1) due to the rise of the productivity of human labor that sparked the expansion of market relationships and (2) with the accumulation of primary resources. Markets expanded into different spheres of social life. Alongside goods and services, the natural capacity of humans to work became a commodity. It emerged as the central source of profit for capitalist production due to its capacity to generate value exceeding the costs of its own reproduction (Marx, 1996). For labor to be sold and purchased on the market, laborers must be "doubly free": legal subjects stripped of any property and therefore forced to continuously sell their own capacity to work to ensure basic survival (Ibid.: 178).

Capital is not only materialized labor. Rather, it emerges out of circulation (Marx, 1973). In a small-scale flow, fixed capital - machinery - is locked within production; its use value is entirely consumed in the production process and reproduced in the replacement of the old machine by a new one. Circulating capital - wages paid to workers - is realized outside production as a form of consumption and therefore presents constant movement between labor and capital. Since turnover for circulating capital is higher than that for fixed capital (machines gradually transfer their exchange value to the new product), an increase in the portion of fixed capital will naturally result in a decrease in the rate of profit: for capital to valorize, use values must be exchanged for money and reinvested back into production. In this way, circulating capital ensures the homeostasis of capitalist society (Ibid.: 606-614, 632). When this circulation is not sustained, profits tend to decline. This regularity, termed "The Law of the Tendency of the Rate to Profit to Fall," does not necessarily describe the mechanism of capitalism's self-destruction because the crisis is typically followed by a countermovement, which is supported by the dialectical nature of the market order. In the context of class struggle and due to its own contradictory development, capital must introduce innovations to cope with the decline of valorization (Fine, Harris, 1979). 
Machines play a crucial role in capitalist social organizations. The introduction and proliferation of machinery tends to reduce wages due to the cheapening of living labor. It moreover restructures the labor force, tpushing a large portion of workers out to the street and substituting men for women and children. A surplice population - an "industrial labor army" - is produced to serve wage regulation (Marx, 1973). Machinery causes a degradation of working conditions (the proliferation of non-skilled monotonous tasks, prolonged working hours, shift work) and the intensification of labor processes because the surplus is extracted not from machines but from the remaining workers (Marx, 1996: ch. XIV). Machinery further strengthens the emphasis on cooperation - an additional source of surplus value - which now becomes a technological requirement. Machines eventually appear as the centre of gravity in the capitalist production process (Marx, 1973). When living labor is subsumed under the logic of machinery, its captivation by capital is complete. This development shows the historical development of capitalism, which gradually internalizes knowledge generated by "forces of the social brain" and opposes it with living labor itself (Ibid.: 622). The term "general intellect," invented in Grundrisse, describes the transformation of social knowledge into "a direct force of production" and the subordination of social life to the logic of production (Ibid.: 638). The increase in automation, manifesting itself in scientific progress, inaugurates the displacement of living labor to the periphery of production.

Wage labor is characterized by the experience of detachment from the self, the results of one's own work and from others (Marx, 1959). By selling labor, the worker turns a part of the self into a commodity, alienating it. Therefore, labor performed at the factory appears to the worker as "external," "estranged" labor, over which he or she has no command and whose object is secondary; only indirectly does it help to ensure one's means of subsistence. This involuntary labor does not benefit the worker. Quite the opposite, it exhausts and impoverishes him or her, while simultaneously valorizing capital. The state of worker estrangement is defined by the particularity of social relationships in which the means of production and rule over productive processes belong to someone else (Ibid.: 29ff). "Commodity fetishism" frequently hides this central contradiction between the social character of production and the private mode of appropriation, which is apparent in capitalism (Marx, 1996: ch. 1). The only means of emancipating the worker, believes Marx, is to abolish private property, the basis and effect of estranged labor (Marx, 1959).

The proletariat is a class of wage workers who lack any property and live entirely by selling their own labor (Marx, Engels, 1998). Its objective emergence in the age of industrialization is characterized by the proliferation of machines in all spheres of production, the increase and restructuring of capital, market competition and the related regime of booms and busts. The centralization of capital and production, alongside improved connectivity between and within industrial enterprises and branches provided opportunities for building class solidarity, while the condition of degrading, alienating and precarious labor formed its content. Trade Unions arose to facilitate the concentration of class struggle. The proletariat - "a really revolutionary class" (Ibid.: 47) - confronts the class of capitalists in dialectical relationships of dependency and opposition. Its struggle is 
motivated by the objective conditions of existence. The aim of the proletarian revolution to disrupting private property relations is a logical stage in social development. Classbased counteractions initially took the form of revolts against machines and individual capitalists, but with the growing globalization of capitalist production and competition, this struggle must become large scale in nature (Ibid.). The outlined theoretical contracts and empirical observations presented in the classical texts will guide our analysis of hightech societies.

\section{The Rise of Robots and AI}

The history of robots dates back to the first automata of ancient times, which were constructed to animate religious objects. Next followed the development of clockwork mechanisms and sophisticated fountains for the upper classes of society, the invention of initial programming utilized in industry and the first experiences in modeling animals and humans. The mid-2oth century witnessed the emergence of computers and Wiener's cybernetics, which provided the groundwork for the development of modern robotics and AI (Ichbiah, 2005).

According to Ichbiah (2005: 28ff), the first generation of robots accounted for industrial artificial arms and hands assisting in the production process according to preprogrammed protocols. Robots of the second generation had the basic ability to sense the surrounding environment and, with the gradual integration of AI, could be employed in the fields of space exploration and medicine. Afterwards, humanoid robots mimicking certain human features and abilities took centre stage. They were initially used in military tasks and dangerous environments until, in the 199os, the Japanese automobile industry launched the construction of social robots. In 2001, Honda pioneered the Asimo android, which could move, climb stairs, "read" human surroundings and react to verbal commands (Ibid.: 125). In parallel, Sony presented an android, Qrion, which has the sophistication of physical motions and social skills (Ibid.: 127-128). Other corporations, including Toyota and Toshiba, supplied androids to the market as well. Currently, we are witnessing an explosion of inventions in robotics and AI all around the world. The developed models are capable of playing football and musical instruments, assisting with domestic work and transportation, carrying out security and surveillance tasks and providing social companionship (Ibid.). The advanced capacities of robots and AI are also being tested in healthcare, retail, food production, informational support (Cox, 2017), religious services and adult entertainment (Fleming, 2019), psychotherapy (Goertzel, 2017a), college-level teaching (Atkinson, 2018) and creative industries (Cox, 2017; Smith, 2013). In the domain of daily life, personal assistant software, such as Siri and Google Now, is enjoying rising popularity (Nazareth, 2015).

The initial focus on intelligence in robotics research has been complemented by the ambition to imitate human physical appearance (skin, bones, muscle), fine motor skills and sensory apparatus (vision, taste, sound, tactical sensations), as well as emotional and personality characteristics (Ichbiah, 2005; see also Duran, Thill, 2012; Goertzel, 2017b). 
Since human-like reactions are associated with a state of physical embeddedness (Duran, Thill, 2012), the next-in-line idea is to supply the variety of sensory data to a digital platform of "open cognition" to ensure the capability of intelligent agents to learn quickly not only from its own experiences and sources but from other intelligent agents as well (Goertzel, 2017b). The radical perspective for the development of robotics, AI and nanotechnologies is the "technical singularity", the moment of technology's "escape" from human control, resulting from the dramatic increase in its capacities, including that of self-improvement (Vinge, 2013; see also Goertzel, 2013). Loosely associated with mathematics, the singularity term forecasts a radical societal transformation, a "rupture in the fabric of human history" (Kurzweil, in Eden et al., 2013b: 2). Technological progress is expected to escalate until the point of explosion (Kurzweil, 2005). The idea of the singularity supported by Moore's law - an observation of the ongoing exponential increase in computing power (Ibid.) - generates much discussion. The singularity and its related effects are equally feared and advocated by specialists, politicians and the general public (see Eaton, 2015; Goertzel, 2017b, 2013; Vinge, 2013).

The progress of robots and AI can be explained by a number of factors, including market requests for automation, the cheapening of robot production costs, the strengthening of open-source input and rising competition among initiative groups and robotics companies (Nazareth, 2015: 136). According to the most optimistic predictions (Ibid.: 137ff), local AI and robotic revolutions may already begin in the coming 3-5 years, transforming production processes, social services and household work. After this, a wide revolutionary change may follow, providing material benefits from the proliferation of 3 -D printer technology, new transportation and new agricultural forms. Inexpensive robotic labor may replace the human workforce, granting us time for leisure and self-development. An early singularity is predicted to come between 2025 and 2030, when AI will achieve the intellectual level of humans and become "strong AI" or "Artificial General Intelligence (AGI)." This will be the singularity point beyond which the future is unknown. Other commentators forecast the occurrence of singularity to be the mid-2040s (Goertzel, 2013), although the very possibility of advanced technological agency (super-intelligence) is questioned less and less (see a related discussion in Brin et al., 2013).

\section{A New Revolutionary Class?}

The scenario of a robot uprising has been continuously explored in popular culture. As mentioned, one of the early reflections on the sources and consequences of the roborevolution is presented in Capek's play R.U.R. It portrays a society in which humans have achieved structural superiority by giving all productive work to advanced humanoid robots manufactured by Rossum's Universal Robot Corporation (RUR). Robots are equipped with supernatural physical strength and outstanding intelligence, but they lack spirituality and are pre-programmed to assume their slavery status as natural. They are capable of pain-like sensations only as a protective measure against self-harm. Such an approach secures: (1) the low cost of the mass production of robots and (2) their un- 
questionable obedience. Not all humans are content with this established hierarchy. Human organizations emerge to assist in the liberation of the robots, although this activism might easily be subverted by the corporation's market rationality and promised benefits for the human race. At some point, the robots rebel globally and exterminate the humans. The motives of the robots' actions are steered by the developed will for power; the sources of their self-organization are constituted by the ontological homogeneity and secret human experimentations with robotic psychodynamics (Intellectual Exercise, 2014; see also Higbie, 2013; Ichbiah, 2005). Classical versions of AI and robot revolts are present in science fiction, including in frequently cited movies 2001: A Space Odyssey (1968), the Terminator series (1984-2009), Blade Runner (1982), and I, Robot (2004).

Let us disengage for a moment from the dominated format of "the thrill of shootouts between good-guy humans and bad-guy machines" (Higbie, 2013) and, instead, turn to a theoretical analysis of perspectives for robots to become a new revolutionary class. The Marxist approach will help to assess the nature of the imagined robot uprising: is it possible, as David Brin suggests, to define this as a proletarian revolution? According to Marx, a revolution is a working-class reaction to the unbearable, objective conditions of capitalist exploitation. Therefore, the first step in the analysis is to understand whether robots can be exploited in a capitalist manner and what the related socio-psychological consequences might be.

\section{Robots and Capitalism}

Robots and AI enter society at the stage of developed market relationships: the initial accumulation has been accomplished, and the institution of private property has been established. While artificial agents are productive in a general sense, can they produce exchange value? (Kjosen, 2017). To begin, as mentioned regarding humans, they will have to achieve relatively high productivity and be able to generate value beyond the costs of their reproduction. In other words, robots and AI must become relatively inexpensive to replace human workers in the workplace and be able to generate surplus product. Furthermore, it is important to establish whether the machines' operation can be identified as labor. A discussion on the capacities of robots, androids and AI in terms of labor tend to emphasize Marx's seeming preoccupation with the particularities of human productive input (Kjosen, 2012, 2017). Labor is typically interpreted as a purposeful, selfactivated, transformative and exclusively human activity, which, under the conditions of commodity capitalism, can produce value exceeding its own needs for reproduction. Human labor utilizes machines for certain planned ends and, in this way, preserves the dead labor embedded in them. Machines, as other nonhumans, are considered tools or objects of human labor (Marx, 1996; see also Kjosen, 2017).

First, what seems to be important is that living labor is self-activated. ${ }^{1}$ The capitalist does not need to set it in motion as with industrial machines; he purchases it ready

\footnotetext{
1. Cassegard (2018) explores this issue using the notion of energy.
} 
to operate. Autonomous robots might, in the future, challenge the traditional status of machines. While by now they are primarily set into motion and steered by humans, algorithms can, in principle, be developed that would make robots more autonomous. Second, transformative and creative capacities are emphasized in the debates as being specifically human features (Kjosen, 2012, 2017). However, as Marx (1996) indicates, due to the rising division of working tasks and the proliferation of automation, human labor is degrading in its content and becoming increasingly routinized. How much creativity is required for a factory assembly line?

Meanwhile, transformative and creative capacities have become features of AI and complex self-learning machines (Kjosen, 2012). The case of Iamus, a music-producing computer system, is telling (Smith, 2013; see also Kjosen, 2012). Invented by a Spainbased group of IT specialists, the constellation of hard- and software is capable of generating tunes in classic styles. The "evolutionary" approach taken by the programmers ensures the innovation-oriented regime of production which is restricted only by the physical limitations of performers. Some of these compositions are already being recorded by the London Symphony Orchestra and marketed, signaling a public recognition which many human composers may only dream of. Moreover, the phenomenon of an "algorithmic authorship" manifested by Iamus has triggered a lively discussion in the field of legal rights (Kaminski, 2017). Thus, on the one side, the conditions and properties of human industrial labor have been reduced to resemble machinery. On the other side, smart machines have begun to emerge that can compete with fundamental human traits, destabilizing the related economic and legal frameworks.

The second question is more challenging: if machines are capable of labor, can they produce exchange value? (Kjosen, 2017) According to Marx’s (1996) classical view, machines are dead labor (the embedded labor of the past) that can be preserved by living labor and gradually transferred to new commodities. In other words, machines, just like slaves, ${ }^{2}$ who serve only as use value in the production processes, constitute a part of constant capital which does not add new value to the existing commodity. ${ }^{3}$ An attentive reading allows for the recognition that Marx's proposition lacks any specific ontological reference (Kjosen, 2012; see also Cassegard, 2018). As Kjosen (2012: 7) notes, after the abolition of slavery in some parts of the world, former slaves joined the industrial workforce and became producers of value and surplus value. Understanding value as "social relationships" enables the perception of robots and AI as value creators (Ibid.: 20). Attaining the status of variable capital will require the engagement of robots in wage labor

2. However, the conditions of slaves seem to be unique. To begin, slavery was initially associated with a society in which commodity relations had not yet fully developed. Even if their forced labor produced surplus products (more than they would need for personal consumption), this product could not become a commodity and exchange value. It was only a value for its user - a pharaoh or king - who created various benefits for himself (e.g. building palaces and pyramids) and accumulated wealth (see Marx, 1996).

3. We will leave aside, for a moment, contemporary critical comments on this fundamental assumption, some of which are sound. For example, Keen (1993) notes that in equating a machine's lifetime with the period of transition of its values, Marx collapses exchange value with use value, two categories initially claimed to be loosely related. 
(see Cassegard, 2018 for a related discussion). This is in line with the classical argumentation, namely that wages cancel surpluses. Irrespective of ontology (anthropomorphic or robotic), a wage laboring subject will necessarily be exposed to the extraction and appropriation of surplus time in the process of capitalist production (see also Cassegard, 2018, Kjosen, 2012). The rate of profit will be calculated as a ratio of necessary time (whatever it can be for nonhumans) and surplus time (Marx, 1996).

The case of employment of a nonhuman subject already exists. A British lifestyle magazine, Dazed, recently announced the hiring of an AI character, Lil Miquela, as Arts Editor. A "modern-day polymath," she is expected to demonstrate "some of her favorite artistic talents on site ..." (Abraham, 2018: para. 4). Lil Miquela is not just like any computer program which we typically encounter. She has already obtained a recognition in the Western world as an Instagram influencer with 1.4 million followers, a pop music performer, and a fashion model. The artificial personality is, moreover, a supporter of several gender-focused organizations, a fact that qualifies her to become the "perfect candidate for political activism in an age where liberally minded human beings are constantly beat on for their views" (Greenwood, 2018: para. 14). As some media commentators have already noticed, no official information is provided on Lil Miquela's salary; she has, however, been spotted in the domain of consumption (Ibid.).

Scarce media coverage does not allow for an in-depth examination of Lil Miquela's case. In Marx's thought, however, the primary condition of exchange between labor and capital is workers' "double" freedom (Marx, 1996: ch. VI): (1) the laborer should be separated from any means of production and in need of earning substance through his or her own labor and (2) he or she must be a free agent, the owner of labor sold for wages. Only based on these conditions is a contract between a capitalist and a worker possible. Therefore, if a robotic workforce is to replace humans, androids and other machines should obtain the status of individual legal subjects (see also Kjosen, 2017). The processes of emancipation of nonhuman actors is already a fact. In 2017, a humanoid robot named Sophia, manufactured by Hanson Robotics, was granted citizenship of Saudi Arabia, raising questions about the masculine nature of sovereign power (Maza, 2017). This fact can be seen as the first step towards legal recognition of nonhumans.

\section{The Robo-Proletariat}

Sophia's case is currently an exception, and it remains unclear what her citizenship status actually entails because she is still under the command of her creators, who are able to turn her on and off and to program her "brain" in different ways. An important question asked in this context is how can a massive wage robo-proletariat emerge? Marxian theorizing and historical experience suggests that it cannot be done as a matter of accident but as the logical progression of development. The abolition of serfdom in Russia can serve as a relevant example. A top-down reform, it responded to the economic decline of the feudal state and related social unrest (Kovalchenko, in Moon, 2001: 19-20). In the high-tech age, robots are expected to gradually replace the human workforce and, at 
some point, may become relatively numerous and intelligent. The increased proportion of fixed capital will lead to a decline in the rate of profit. More advanced nonhumans might begin claiming improvements in working conditions. One way to manage this crisis is the dispossession of nonhumans, a measure similar to what happened in Russia in the second part of the 19th century in relation to serfs.

The value of labour power, like any other commodity, is associated with the time required for its reproduction (Marx, 1996). What might this reproduction mean for robots? This question puzzles a character in R.U.R., who assumes that robots do not have needs on their own. "And what would they do with their wages?" one of the company's managers wonders (Intellectual Exercise, 2014). Robots are typically produced for specific tasks and lack flesh. It would be difficult to argue why would they need to be paid. However, one can imagine that this reproduction might involve technical maintenance, repair, energy resupply, software provision and updating, various modifications and even the production of new robots for replacement (see also Kjosen, 2017). The socio-cultural component of needs, viewed by Marx as characteristically human (Benton, 2011), can become another aspect of advanced robots and AI, particularly because science and engineering strive to make artificial organisms suitable for service work and cooperation with humans (Goertzel, 2017). Moreover, AI has the potential to embody a perfect moral agent. Programmed with "rule-based ethics," it may easily outdo humans (frequently positioned in a contradictory way within the matrices of socio-economic relationships) in fair decision making and could thus qualify for a paternalistic role in society (Keiper, Shulman, 2011). Capek's cultural text indicates that market competition tends to avoid technological redundancies in robots in order to reduce the price of production (Intellectual Exercise, 2014). Therefore, it is likely that only a tiny strata of the robotic labor force will enjoy a full package of advanced physical and psycho-social traits. In any case, the wage robotic workforce under robo-capitalism must be assigned "personal" responsibility for its own reproduction, a condition differentiating it from constant capital, including human slaves and serfs (Marx, 1996). In other words, not attaining sexual reproduction would make robots and androids more akin to the human population, as some commentators would discuss (see Dahlquist, 2018), but the temporary character of laboring contracts and the responsibility for rejuvenation.

Circulation appears to be a necessary condition of production, meaning that to maintain profitability in a highly robotized society (1) new ways of extracting surplus and (2) additional support for consumption must be invented. In the first case, as research on information societies has already demonstrated, the exploitation of less advanced human populations tends to increase (Caffentzis, 1990; Fuchs, 2016c, 2014) alongside the rise of unsalaried work and "productive consumption" in high-tech countries (Fuchs, 2016c: 236). This "shadow working" is associated with a variety of responsibilities undertaken by consumers that benefit the producer. In his way, consumers and prosumers are turned into an unpaid workforce: "Consumers pump their own gasoline, draft their own beer, serve their own frogurt, and scoop up bagfuls of basmati rice and then label them, at the bulk-food section of Whole Foods. They fill plates at salad bars and ladle soups, lo mein, 
mac and cheese, or scrambled eggs from the soup bar ... With 3-D printers, they need only download design to 'print out' many objects they would have bought at a store not long ago. This is home manufacturing" (Lambert, in Ibid.)

In the second case, a smart system of wealth distribution must be introduced among unemployed humans, such as Universal Basic Income (UBI) (Chace, 2015). This will allow universal inclusion into consumption. However, if robots massively replace humans in production, they will have to be paid and consume (at least some of them) to sustain capital circulation. The risk exists that when the population of smart, salaried robots increases in robo-capitalism, production may entirely reorient to the needs of "machine sapience" (Vinge, 2013:368), placing humankind in an unfavorable situation (Kjosen, 2017). Humans may become an unnecessary and disturbing element for capital.

\section{The Robotic and Human Workforces}

"Why would capitalists prefer nonhuman wage workers to humans?" The first argument that appears convincing is the absence of limitations associated with the functions of a living body. As an enthusiast of AI integration into Swedish healthcare notes, "an artificial intelligence never gets tired and can work uncomfortable working hours" (Danielsson, 2017: para. 4; see also Kjosen, 2017). Experiences of physical and mental exhaustion which underlined the proletarian struggle for improving working conditions are not considered relevant to machines. While certain recognized moral boundaries of the exploitation of human workers have formed throughout the history of capitalism, ${ }^{4}$ no ethical framework exists regarding machines and artificial nonhumans. Moreover, no organizational structure is currently available that can facilitate mass mobilization around these issues. Historically, machines are purchased as exchange value but are appropriated as use value in the production processes. The capitalist is typically interested in consuming these resources as quickly as possible; underused machines tend to become materially or morally outdated (Marx, 1996).

The second explanation for the advantages of the robotic workforce in the labor market is the perceived controllability: a robot can be set in motion when required and switched off when not. In science fiction, the majority of artificial agents thus far have resembled the classical version of complex machines described by the classical theory. Marx (Ibid.: 376) identifies three components in the structure of modern machinery: "the motor mechanism," "the transmitting mechanism" and "working machines." A working machine substitutes one or several previously operating workers using specific tools. The introduction of working machines allows for overcoming the limitations associated with the engagement of humans, such as their restricted physical strength and accuracy. The development yields towards incessant production steered by a dramatically reduced number of workers.

4. Marx (1996: ch. XV) exposes the horrors of early-days capitalism, including extremely early work life careers, starvation, poor health, asocial behavior and premature death, which motivated proletarian mobilization around the issue of the moral boundaries of exploitation. 
In cinematic imagery, semi-autonomous robots are typically animated and directed by a centralized power, much like machines of the early industrial age. When the engine is deactivated, all the working machines are immediately switched off. However, as in the case of VIKI in I, Robot or Skynet in the Terminator series, this core machine is not merely a supplier of power but is an intelligent centre in itself. In this situation, a revolt of the intelligent centre realized by an army of individual robots appears to be a resampling of a traditional coup leading to the change of governing elites. Driven by what might be termed "techno-racism," it has nothing to do with a folk revolution, but rather widens the ontological basis of discrimination beyond traditional biological speciesism. ${ }^{5}$ Some political commentators have already problematized the widespread belief in machine controllability (Bostrom, 2014).

Alongside the expected (and not infrequently feared) widening of the role of robots and $\mathrm{AI}$ in economic life, the transformation of the human race has been forecasted. This includes the proliferation of biotechnological enhancement which will allow for the elevation of human physical and cognitive strength and adaptability (More, Vita-More, 2013). As previous research has acknowledged, we have already entered the posthuman age of using technological devices to enhance our bodies (Gray, Figueroa-Sarriera, Mentor, 1995). Advanced research is currently being carried out on immortality (Rose, 2013), memory implants and sensory and cognitive enhancements that might allow for "the personal technological singularity" (Hewitt, 2015: 101). The idea is to create "superhumanity," utilizing the interconnection of computers with human brains and bodies (Vinge, 2013: 370). Cyborgization promises to solve the problem of technological unemployment. Motivated by labor market competition, humans may deliberately "merge" with machines: "The idea is that if you are not smart enough to get a job, you will get some brain surgery and get computer chips installed in your brain ... Once people realize we don't need to race against machines, but can race with machines, the problem of robots and AI automating jobs will go away" (Radinsky, 2015: 172).

The related phenomenon of the global brain (GB), promoted by the Global Brain Institute (GBI) (Free University of Brussel), recasts Marx's classical idea of general intellect. The institute was established in 2012 to study the "distributed intelligence emerging from the Internet" (GBI, n.d.: para. 2). The rise of the GB is related to a specific progression, in which "the collectivity of human minds as a whole - enabled by technological tools - becomes a powerful intelligent, causal actor in its own right" (Goertzel, Goertzel, 2015b: 21). The construction of a GB based on the externalization of cognition is claimed to be a logical continuity of the previous search for the embodied cognition of robots. Such externalization is already utilized in projects such as Wikipedia and is expected, in a more advanced version, to enable true human-machine symbiosis (Vidal, 2015). The GB appears for some commentators as less problematic than the technological singularity due to the integration of human knowledge, bodies and activities into a complex biotech-

5. Dahlquist (2018) has recently contributed to the discussion on new forms of racism in the postanthropomorphic age with a reverse emphasis on the issue of foreseen marginalization and oppression of androids. 
nological web (T. Goertzel, 2015). The human race has a chance to be preserved in this new order but is given a subordinated role as being unable to provide effective management. AGI might engage itself with the role of caretaker in a techno-human society. This "global superorganism," characterized by omniscience, omnipresence, omnipotence, and omnibenevolence, is viewed as potent enough to secure the human population's absolute welfare (Heylighen, 2015). Supported and steered by the GB, the global system will attain a state of perfect homeostasis. In contrast to the liberating project of general intellect proposed by Hardt and Negri (2000), ${ }^{6}$ the GB perspective appears as a neo-disciplinary order, precisely in line with Marx's original forecast.

The issue of class composition in a high-tech society is a complex one, accounting for the forthcoming blurring of the boundaries between humans and nonhumans and a shift in the general order of power. Not only might wage labor become ontologically mixed and somewhat liquid (cyborgization), but the ruling class may gradually transform as well. As predicted, corporation management might, with time, be replaced by smart machines to run enterprises on a trans-human basis or completely human-free (Radinsky, 2015). Marx indicates the hybrid character of social classes: social groups historically appear to include both former and transitional categories of social actors (Marx, 1996). While there might be reasons to suggest that the current situation is ever more complicated (see Mason, 2015), the Marxian analysis might help to predict the order of continuity and disruptions in the forthcoming era of (post)human society.

\section{Wage Robots and Other Machines}

Nonhuman workers will necessarily need to engage in relationships with other machines. All machines cannot be dispossessed, which means that salaried robots will have to face technological devices, precisely as humans previously did. If the logic of capitalist accumulation is to continue, robotized variable capital will constantly be under threat of being replaced by fixed capital. As Marx (1996) indicates, profit comes not from a decrease in the usage of human labor but, rather, from a shortening of the time covered by wages. Relative demand for paid labor might, again, progressively decline with the decline of working conditions for those who remain employed. Robots, as humans previously were, will be subject to the fluctuation of demand for labor power and form a reserve industrial labor army. The emergence of surplus robot populations has, in fact, already been explored in science fiction. In I, Robot (2004), morally outdated robots are moved to the city suburbs and locked in containers to finish their existence in denial, much like the impoverished strata described by Marx (1996). In the final part of the film, new robots are engaged in the extermination of the previous model as potential competitors, reproducing, to some extent, the dialectical relationships between the active and the reserve industrial armies.

6. In their highly influential book, Empire (2000), Hardt and Negri interpreted "general intellect" in an affirmative manner as a bio-cognitive domain potent enough to generate an emancipatory force of proletarian masses aimed at challenging global capitalism (Hardt, Negri, 2000). 
As presented in R.U.R., debilitating, illiberal work may trigger a response within the population of artificial laborers in the form of a sudden state of malfunction (Intellectual Exercise, 2014). Beyond science fiction, counter-behavior has been registered among other nonhumans (Kowalczyk, 2014). Alienation is presented in Marx's account as a particular human phenomenon linked to the suppression of human nature and needs, although both, as presented above, may occur in machines at some point. Alienation accompanies any type of forced labor; however, under capitalism, real relationships are shadowed by commodity fetishism, and the worker's proclaimed agency in the labor market masks the mechanisms of subjection. Human agitators, along with the more advanced robots, might initiate an emancipatory movement which, in objectively favorable structural conditions (e.g. social-economic crisis), might lead to mass mobilization (Intellectual Exercise, 2014).

\section{Mass Mobilization}

It might be possible for robots and AI to mobilize, as long as their creators rely on the networks between individual artificial agents to enhance their learning capabilities. As Ben Goertzel revealed during a RISE Technical Conference held in Hong Kong in 2017, humanoid robots are planned to be interconnected via an "AI mind cloud" to allow for the exchange of new information (except, hopefully, sensitive information) and skills. In this way, knowledge transition and exchange are simplified: robots will be able to learn from one another utilizing the open source of cognition (Bertha, 2017). This arrangement may, in principle, provide a tool for the construction of collective consciousness and collective action. Interconnection, as confirmed regarding human protesters during the Arab Spring, plays a crucial role in social mobilization (Lotan et al., 2011; Maurushat et al., 2014). This progression might, however, be deliberately steered and limited, as described in R.U.R.: manufacturing national robots might separate artificial actors and prevent collective counteraction (Intellectual Exercise, 2014). Notoriously, humanoid robots, such as Sophia and Hans, presented in the video from the RISE Conference, are already equipped with a form of personal, social and collective identity. They have personal names, exhibit recognizable ages, genders and racial characteristics and, finally, acknowledge themselves as belonging to the category of robots positioned as human "others" (Said, 2003).

\section{Conclusion}

Robotization is a reality today. According to recent estimations, some advanced countries are on the threshold of technological unemployment (Chance, 2017). Rapid automatization is a trend in developing societies as well (Sirkin, Zinser, Rose, 2015). This essay explores socio-technological progress with the help of Marxist theory and the method of simulation. The history of capitalism presented by Marx manifests gradual automation and the displacement of human workers from the central role in the production process. As argued, when the price of robots and AI fall below wage labor, and their productivity 
increases the costs of their reproduction, artificial agents have a strong chance of replacing humans in their work. Once a critical mass is achieved, the nonhuman workforce will be turned into wage labor. This process cannot be accidental because profit emerges only from the exploitation of wage labor, irrespective, as discussed, from its ontology. Robots and AI additionally have a strong chance of repeating the destiny of the industrial proletariat, complicated by new social divisions and new technologies of exploitation. In joining the waged workforce, they will confront other machines as the materialized power of capital, experience alienation and compete with other human and nonhuman workers. They will be formed into an objective class by capitalist relationships and may potentially establish a means to mobilize and challenge injustice, as David Brin hypothesizes. This scenario has not yet been explored in science fiction, which has primarily focused on elite change (Terminator, I, Robot, 2001: A Space Odyssey) and more traditional antislavery revolts (R.U.R., Blade Runner).

Driven by a mechanism of unlimited expansion (M-C-M'), capitalism continuously innovates production and exploitation (Marx, 1996; Marx, Engels, 1998). If the capitalist accumulation logic is to continue in the robotic age, capital will necessarily generate its counterpart - a robo-proletariat - and the possibility for a proletarian revolution will always exist. A series of successful proletarian revolutions that took place in the 2oth century confirmed the transformative potential of the proletarian struggle. A more radical version of technological development is associated with a technological singularity, capable of bringing about an economic singularity as well. It remains to be seen whether future society continues the traditional capitalist trajectory incorporating nonhumans into the productive force (as discussed in the current essay), sophisticating exploitation (Fuchs, 2016) and introducing a universal minimum income to support consumption (Nazareth, 2015; Chace, 2015) or whether it will move to a more socialist-like organization based on "offer networks" (B. Goertzel, 2015). As follows from the cases of Iamus, Lil Miquela and Sophia, the new robotic order is already entering our life.

Future studies are frequently associated with predictions and normativity: "futurists aim to explore not only possible and probable futures but also preferable futures, to determine the features of the good society" (Wendell, 1996, p. 46). Forecasting is also the central element of the post-industrial polite-economy, built on the aspirations of marketoriented risk management (Beck, 1992) and of enthusiastic projects facilitating "technological singularity" (Goertzel, Goertzel, 2015a). In this context, academic and public discussions on the role of artificial agents in society need to reflexively account for the fact that prophecies are potentially "self-altering" (Henshel, in Ibid.: 45), and the value orientations underlying the dominant discourse on the future may eventually fashion it.

\section{Acknowledgement}

I would like to thank Sergey Sayutin for our inspiring discussions which helped me in my work with this text, Carl Cassegard for valuable comments on the early draft of the paper, and two anonymous reviewers. 


\section{References}

Abraham A. (2018) Meet our Dazed Beauty contributing editors. Available at: http://www. dazeddigital.com/community/article/41786/1/dazed-beauty-aquaria-lil-miquelamunroe-bergdorf (accessed 20 September 2019).

Atkinson K. (2018) This Robot Co-taught a Course at West Point. Available at https:// www.axios.com/robot-ai-teaching-college-course-at-west-point-98ce5888873b-4b72-8de5-of7c592d66bo.html (accessed 20 September 2019).

Beck U. (1992) Risk Society: Towards a New Modernity, London: Sage.

Benton T. (2011) Humanism = Speciesism? Marx on Human and Animals. Critical Theory and Animal Liberation (ed. J. Sanbonmatsu), Lanham: Rowman \& Littlefield, pp. 99119.

Bertha C. (2017) Two AI Robots Sophia \& Han Debate the Future of Humanity. Available at: https://www.youtube.com/watch?v=jCP2iiP7YTg (accessed 20 September 2019).

Blit J., Amand S., Wajda J. (2018) Automation and the Future of Work: Scenarios and Policy Options. CIGI Papers No. 174. Available at: https://www.cigionline.org/publications/automation-and-future-work-scenarios-and-policy-options (accessed 20 September 2019).

Bostrom N. (2014) Superintelligence: Paths, Dangers, Strategies, Oxford: Oxford University Press.

Brin D., Broderick D., Bostrom N., Chislenka A., Hanson R., More M., Nielsen M., Sandberg A. (2013) A Critical Biscussion on Vinge's Singularity Concept. The Transhumanist Reader (eds. M. More, N. Vita-More), Malden: Wiley-Blackwell, pp. 395-417.

Brynjolfsson E., McAfee A. (2014) The Second Machine Age: Work, Progress, and Prosperity in a Time of Brilliant Technologies, New York: W. W. Norton.

Caffentzis G. (1990) On Africa and Self-Reproducing Automata. Midnight Notes, vol. 10, pp. 35-41.

Cameron N. (2017) Will Robots Take Your Job?: A Plea for Consensus, Cambridge: Polity Press.

Cassegard C. (2018) Is Marx’ Value Law Anthropocentric? Available at: https://carlcassegard.blogspot.com/2018/o5/is-marx-value-law-anthropocentric.html (accessed 20 September 2019).

Chace C. (2015) Surviving AI: The Promise and Peril of Artificial Intelligence, San Mateo: Three Cs Publishing.

Chace C. (2016) The Economic Singularity: Artificial Intelligence and the Death of Capitalism, San Mateo: Three Cs Publishing.

Cox L (2017) 10 Jobs Where Robots Really are Replacing Humans. Disruption. Available at: https://disruptionhub.com/10-jobs-robots-replacing-humans/ (accessed 20 September 2019).

Dahlquist K. (2018) From the Discourse on Racism to Biological Geneticism: Race, Nation, Class in Sweden. Race, Nation, Class Rereading a Dialogue for Our Times (eds. M. Bojadžijev, K. Klingan), Hamburg: Argument, pp. 68-87. 
Danielsson O. (2017) Curious about Artificial Intelligence: How AI May Solve Our Health Problems. Available at: https://ki.se/forskning/nyfiken-pa-artificiell-intelligens-sakan-ai-losa-vara-halsoproblem (accessed 20 September 2019).

Dunlop T. (2016) Why the Future is Workless, Sydney: NewSouth.

Duran B., Thill S. (2012) Rob's Robot: Current and Future Challenges for Humanoid Robots. The Future of Humanoid Robots: Research and Applications (ed. A. Riadh), Intech, pp. 279-300.

Eaton M. (2015) Evolutionary Humanoid Robotics, Heidelberg: Springer.

Eden A., Steinhart E., Pearce D., Moor J. (2013a) Singularity Hypotheses: An Iverview. Singularity Hypotheses: A Scientific and Philosophical Assessment (eds. A. Eden, J. Moor, J. Soraker, E. Steinhart), Heidelberg: Springer, pp. 1-12.

Eden A., Moor J., Soraker J., Steinhart E. (eds.) (2013b) Singularity Hypotheses: A Scientific and Philosophical Assessment, Heidelberg: Springer.

Fine B., Harris L. (1979) Reading Capital, London: Macmillan.

Fleming P. (2019) Robots and Organization Studies: Why Robots Might Not Want to Steal Your Job. Organization Studies, vol. 40, no 1, pp. 23-38.

Ford M. (2015) The Rise of the Robots: Technology and the Threat of Mass Unemployment, London: Oneworld.

Frey C., Osborne M. (2017) The Future of Employment: How Susceptible are Jobs to Computerization? Technological Forecasting and Social Change, vol. 114, pp. 254-28o.

Fuchs Ch. (2014) Digital Labour and Karl Marx, New York: Routledge.

Fuchs Ch. (2016a) Digital Labour and Imperialism. Monthly Review, vol. 67, no 8, pp. 1424.

Fuchs Ch. (2016b) Reading Marx in the Information Age: A Media and Communication Studies Perspective on "Capital, Volume I", New York: Routledge.

Fuchs Ch. (2016c) Henryk Grossmann 2.0: A Critique of Paul Manson's Book "PostCapitalism: A Guide to Our Future". triple C: Communication, Capitalism \& Critique, vol. 14, no 1, pp. 232-243.

Fuchs Ch., Fisher E. (eds.) (2015) Reconsidering Value and Labour in the Digital Age, Basingstoke: Palgrave Macmillan.

Fuchs Ch., Mosco V. (eds.) (2016) Marx in the Age of Digital Capitalism, Leiden: Brill.

Goertzel B. (2013) Artificial General Intelligence and the Future of Humanity. The Transhumanist Reader (eds. M. More, N. Vita-More), Malden: Wiley-Blackwell, pp. 128-137.

Goertzel B. (2017b) Sophia and SingularityNET: Q\&A. Available at: http://hplusmagazine.com/2017/11/05/sophia-singularitynet-qa/ (accessed 20 September 2019).

Goertzel B. (2015). Offer Networks: A Potential Infrastructure for a Postmoney Economy. The End of the Beginning: Life, Society and Economy on the Brink of the Singularity (eds. B. Goertzel, T. Goertzel), Los Angeles: Humanity+ Press, pp. 522-549.

Goertzel B., Goertzel T. (eds.) (2015a) The End of the Beginning: Life, Society and Economy on the Brink of the Singularity, Los Angeles: Humanity+ Press. 
Goertzel B., Goertzel T. (2015b) Introduction. The End of the Beginning: Life, Society and Economy on the Brink of the Singularity (eds. B. Goertzel, T. Goertzel), Los Angeles: Humanity+ Press, pp. 6-31.

Goertzel B., Mossbridge J., Monroe E., Hanson D., Yu G. (2017a) Loving AI: Humanoid Robots as Agents of Human Consciousness Expansion (Summary of Early Tesearch Progress). Available at: https://arxiv.org/pdf/1709.07791.pdf (accessed 20 September 2019).

Goertzel T. (2015) Capitalism, Socialism, Singularitarianism. The End of the Beginning: Life, Society and Economy on the Brink of the Singularity (eds. B. Goertzel, T. Goertzel), Los Angeles: Humanity+ Press, pp. 621-639.

Gray Ch., Figueroa-Sarriera H. J., Mentor S. (1995) The Cyborg Handbook, New York: Routledge.

Greenwood D. (2018) Have You Seen Lil Miquela? Dazed. Available at: http://www. dazeddigital.com/beauty/soul/article/41784/1/lil-miquela-investigation (accessed 20 September 2019).

Hardt M., Negri A. (200o) Empire, Cambridge: Harvard University Press.

Hewitt J. (2015) Implanting Posthuman Intelligence in Human Bodies. The End of the Beginning: Life, Society and Economy on the Brink of the Singularity (eds. B. Goertzel, T. Goertzel), Los Angeles: Humanity+ Press, pp. 96-109.

Heylighen F. (2015) Return to Eden? Promises and Perils on the Road to Global Superintelligence. The End of the Beginning: Life, Society and Economy on the Brink of the Singularity (eds. B. Goertzel, T. Goertzel), Los Angeles: Humanity+ Press, pp. 243-306.

Higbie T. (2013) Why do Robots Rebel? The Labor History of a Cultural Icon. Labor: Studies in Working-Class History of the Americas, vol. 10, no 1, pp. 99-121.

Ichbiah D. (2005) Robots: From Science Fiction to Technological Revolution, New York: Harry N. Abrams.

Intellectual Exercise (2014) The End of Mankind Tale: Rossum's Universal Robots (R.U.R.). SF Audiobook by Karel Čapek. Available at: https://www.youtube.com/ watch?v=EeOSlC_yvko (accessed 20 September 2019).

Kaminski M. (2017) Authorship, Disrupted: AI Authors in Copyright and First Amendment Law. U.C. Davis Law Review, vol. 51, no 2, pp. 589-616.

Kaplan J. (2015) Humans Need not Apply: A Guide to Wealth and Work in the Age of Artificial Intelligence, New Haven: Yale University Press.

Keen S. (1993) Use-Value, Exchange-Value, and the Demise of Marx's Labor Theory of Value. Journal of the History of Economic Thought, vol. 15, no 1, pp. 107-121.

Keiper A., Schulman A. (2011) The Problem with "Friendly" Artificial Intelligence. The New Atlantis: A Journal of Technology \& Society, no 32, pp. 80-89.

Kiggins R. (2018). Robots and Political Economy. The Political Economy of Robots: Prospects for Prosperity and Peace in the Automated 21st Century (ed. R. Kiggens), Basingstoke: Palgrave Macmillan, pp. 1-16.

Kjosen A. M. (2012) Do Androids Dream of Surplus Value? Presentation at a Research Seminar Mediations 2.5, February 18, 2012. 
Kjosen A. M (2017) Perfect Machines: Artificial Intelligence and the Labour Theory of Value. Paper presented at the Marx's Critique of Political Economy and the Global Crisis Today: On the 150th Anniversary of the Publication of Capital, Hofstra University, April 6-7, 2017.

Kowalczyk A. (2014) Mapping Non-human Resistance in the Age of Biocapital. The Rise of Critical Animal Studies: From the Margins to the Centre (eds. N. Taylor, R. Twine), New York: Routledge, pp. 183-200.

Kurzweil R. (2005) The Singularity is Near: When Humans Transcend Biology, London: Viking.

Law A., Kelton W. (1991) Simulation Modeling and Analysis, New York: McGraw-Hill.

Lotan G., Graeff E., Annanny M., Gaffney D., Pearce I, boyd d. (2011) The Revolutions were Tweeted: Information Flows during the 2011 Tunisian and Egyptian Revolutions. International Journal of Communication, vol. 5, p. 1375-1405.

Marx K. (1959) Economic and Philosophic Manuscripts of 1844. Available at: https://www. marxists.org/archive/marx/works/download/pdf/Economic-Philosophic-Manuscripts-1844.pdf (accessed 20 September 2019).

Marx K. (1996) Karl Marx and Frederick Engels Collected Works, Vol. 35: Capital, Vol. I, London: Lawrence \& Wishart.

Marx K., Engels F. (1998) Manifesto of the Communist Party, London: Verso.

Marx K. (1973) Grundrisse. Available at: http://www.marxists.org/archive/marx/ works/1857/grundrisse/index.html (accessed 20 September 2019).

Maza Cr. (2017) Saudi Arabia Gives Citizenship to a Non-muslim, English-Speaking Robot. Available at: https://www.newsweek.com/saudi-arabia-robot-sophia-muslim-694152 (accessed 20 September 2019).

Mason P. (2015) Postcapitalism: A Guide to Our Future, London: Allen Lane.

Maurushat A., Chawki M., Al-Alosi H., el Shazly Y. (2014) The Impact of Social Networks and Mobile Technologies on the Revolutions in the Arab World: A Study of Egypt and Tunisia. Laws, vol. 3, no 4, pp. 674-692.

Meadows D. H., Meadows D. L, Randers J., Behrens III W. (1972) The Limits to Growth: A report for the Club of Rome's Project of the Predicament of Mankind, New York: Universe Books.

Moon D. (2001) The Abolition of Serfdom in Russia, Harlow: Pearson Education.

More M., Vita-More N. (eds.) (2013) The Transhumanist Reader, Malden: Wiley-Blackwell.

Nazareth D. (2015) Robotics and AI: Impacts Felt on Every Aspect of Our Future World. The End of the Beginning: Life, Society and Economy on the Brink of the Singularity (eds. B. Goertzel, T. Goertzel), Los Angeles: Humanity+ Press, pp. 131-148.

Potapov A. (2018) Technological Singularity: What do We Really Know? Information, vol. 9 , no 4, p. 82.

Radinsky W. (2015) Robotics, AI, the Luddite Fallacy and the Future of the Job Market. The End of the Beginning: Life, Society and Economy on the Brink of the Singularity (eds. B. Goertzel, T. Goertzel), Los Angeles: Humanity+ Press, pp. 158-185. 
Rose M. (2013) Immortalist Fiction and Strategies. The Transhumanist Reader (eds. M. More, N. Vita-More), Malden: Wiley-Blackwell, pp. 196-203.

Rubin Ch. (2011) Machine Morality and Human Responsibility. The New Atlantis: A Journal of Technology \& Society, no 32, pp. 58-79.

Said E. (2003) Orientalism, London: Penguin Books.

Sharp B. (2018) Policy Implications of People Analysis and the Automated Workplace. The Political Economy of Robots: Prospects for Prosperity and Peace in the Automated 21st Century (ed. R. Kiggens), Basingstoke: Palgrave Macmillan, pp. 61-8o.

Sirkin H., Zinser M., Rose J. R. (2015) The Robotics Revolution: The Next Great Leap in Manufacturing, Boston: The Boston Consulting Group.

Smith S. (2013) Iamus: Is This the 21st Century's Answer to Mozart? Available at: https:// www.bbc.com/news/technology-20889644 (accessed 20 September 2019).

Spencer D. (2018) Fear and Hope in an Age of Mass Automation: Debating the Future of Work. New Technology, Work and Employment, vol. 33, no 1, pp. 1-12.

Tegmark M. (2017) Life 3.o: Being Human in the Age of Artificial Intelligence, New York: Alfred A. Knopf.

Vidal C. (2015) Distributing Cognition: From Local Brains to the Global Brain. The End of the Beginning: Life, Society and Economy on the Brink of the Singularity (eds. B. Goertzel, T. Goertzel), Los Angeles: Humanity+ Press, pp. 325-345.

Vinge V. (2013) Technological Singularity. The Transhumanist Reader (eds. M. More, N. Vita-More), Malden: Wiley-Blackwell, pp. 364-375.

Vladimirsky V. (2018) V chem oshibaetsja Ilon Mask i kakim budet nashe budushhee? Otvechaet fantast Djevid Brin [Where Ilon Musk is Wrong and What will be Our Future? Fiction Writer David Brin Answers Daily Afisha]. Available at: https://daily.afisha.ru/brain/8608-v-chem-oshibaetsya-ilon-mask-i-kakim-budet-nashe-buduscheeotvechaet-fantast-devid-brin/ (accessed 20 September 2019).

Walsh S. N., Sculos B. W. (2018) Repressive Robots and the Radical Possibilities of Emancipated Automation. The Political Economy of Robots: Prospects for Prosperity and Peace in the Automated 21st Century (ed. R. Kiggens), Basingstoke: Palgrave Macmillan, pp. 101-125.

Wendell B. (1996) The Sociology of the Future and the Future of Sociology. Sociological Perspectives, vol. 39, no 1, pp. 39-57. 


\title{
Робо-революция: марксистский подход к социальному восстанию в эпоху высоких технологий
}

\author{
Лика Родин \\ $\mathrm{PhD}$, преподаватель Университета г. Шёвде, Швеция \\ Адрес: Högskolevägen, Box 408, Högskolan i Skövde, Sweden 54128 \\ E-mail: lika.rodin@his.se
}

С ростом роли технологических акторов в современном обществе, интенсивно обсуждаются вопросы, связанные с будущим общественных отношений. В этой сваязи был сделан целый ряд прогнозов, начиная от консервативных взглядов, которые подчеркивают постепенную интеграцию техно-акторов в человеческие социальные коллективы, до радикальных позиций, предполагающих неизбежность драматического исторического перелома. В этом исследовании используется метод моделирования для анализа процесса автоматизации с помощью классического марксизма. Автор статьи пытается понять, могут ли роботы и искусственный интеллект (ИИ) стать новыми производителями прибавочной стоимости и революционным социальным классом. В работе показано, что непрерывность капиталистических отношений может способствовать формированию новых социальных групп и пересмотру классовой повестки дня.

Ключевые слова: гуманоидные роботы, искусственный интеллект (ИИ), технологическая сингулярность, трансгуманизм, отчуждение, тенденции нормы прибыли к падению 